\title{
Grażyna Pańko, Polska i Polacy w czeskiej opinii publicznej w okresie międzywojennym, Wrocław 1996, ss. 218
}

Najnowsza książka Grażyny Pańko przedstawia wizerunek Polski i Polaków w czeskiej opinii publicznej w okresie międzywojennym. Funkcjonujące tam i utrwalane, a także tworzone dla doraźnych celów politycznych opinie o sąsiadach z północy - jak dokumentuje autorka - były zazwyczaj krytyczne, a czasem nawet bardzo negatywne. Dawało to o sobie znać szczególnie w okresach napiętych stosunków pomiędzy Polską a Czechosłowacją, zwłaszcza w latach 1918-1920 i potem po 1934 roku.

Praca niniejsza oparta jest, jak pisze we wstępie autorka, przede wszystkim na prasie satyrycznej, „która przez karykatury i wierszyki wyakcentowuje - celowo przejaskrawiając - cechy, których nie akceptuje, aby je uwidocznić i wywołać ich negację u czytelnika. Jest to jeden ze sposobów odreagowania własnych nastrojów i uprzedzeń, ale też kształtowania opinii publicznej" (s. 5). Wykorzystano ponadto przysłowia, literaturę piękna, kalendarze, publicystykę oraz prasę codzienną, z której udało się autorce zebrać najwięcej danych do niniejszego tematu. Użyteczne też okazały się opinie na temat Polski i Polaków wypowiadane przez czołowych polityków czechosłowackich oraz posłów Zgromadzenia Narodowego, które uznano za „znaczący przejaw opinii publicznej” (s. 8).

Niezrozumiałe i odbiegające od stanu faktycznego jest stwierdzenie autorki, że: „W pracy nie uwzględniono pamiętników, ponieważ ich w zasadzie nie ma” (s. 9). A przecież są pamiętniki zarówno Edvarda Beneša, jak i Tomáša G. Masaryka (osobną kwestią jest to czy i na ile są one ważne i przydatne dla tematu). Zresztą potem pojawiają się one w wykazie źródeł i literatury, tyle że w wyodrębnionej grupie pod nazwą Pisma polityczne. Także w tekście wykorzystano niektóre wypowiedzi tychże polityków, o czym świadczą również cytaty. Poza tym autorka przytacza także wypowiedzi na temat Polski Kamila Krofty (z jego nie publikowanych Dzienników).

Jak wiadomo Beneš i Masaryk kształtowali w głównej mierze politykę Czechosłowacji, w tym także stosunki z Polską. Wpływali oni też na atmosferę wzajemnych relacji, jak również kreowali w niemałym stopniu opinie na temat Polski 
i Polaków. I to na użytek zarówno rodzimej opinii publicznej, jak i międzynarodowej. Dało to o sobie znać już w czasie I wojny światowej i obrad konferencji paryskiej, jak również potem w kolejnych latach niepodległego bytu Czechosłowacji.

Czesi przywiązywali dużą rolę do propagandy za granicą i nieprzypadkowo zarówno Beneš, jak i Masaryk, a potem Ministerstwo Spraw Zagranicznych tym kwestiom poświęcało tak wiele uwagi. Książki i pamiętniki Masaryka oraz opracowania obcojęzyczne na temat Czechosłowacji i jej miejsca w Europie Środkowej (w tym kontekście często pojawiała się Polska) spełniły ważną rolę w odbudowie niepodległej Czechosłowacji i kreowaniu jej wizerunku za granicą. Ponadto liczne przemówienia Masaryka i Beneša oraz opracowania na temat Czechosłowacji i jej polityki były nieraz tłumaczone na język angielski, francuski i niemiecki, dzięki czemu docierano $\mathrm{w}$ ten sposób $\mathrm{z}$ argumentami i tezami czeskimi do opinii zagranicznej. Praski MSZ przeznaczał znaczne sumy na finansowanie akcji informacyjno-propagandowej o Czechosłowacji i jej polityce, co w znacznej mierze przyczyniło się do wykreowania pozytywnego wizerunku młodej republiki.

W rozdziale I autorka, omawiając stosunki polsko-czechosłowackie w okresie międzywojennym w świetle czeskiej opinii publicznej, sporo uwagi poświęciła przyczynom konfliktów pomiędzy dwoma sąsiedzkimi krajami. Głównym powodem wzajemnej wrogości był zatarg o Śląsk Cieszyński w latach 1918-1920, a potem także, choć w znacznie mniejszym stopniu, polskie pretensje do Spisza, Orawy i tatrzańskiej doliny Jaworzyny (s. 13-16). W gruncie rzeczy decyzja Rady Ambasadorów z 28 lipca 1920 roku i podział Śląska Cieszyńskiego nie zadowolił żadnej ze stron, a w przyszłości problem mniejszości polskiej w Czechosłowacji rzutował także na wzajemne stosunki.

W 1925 roku, a zwłaszcza w obliczu konferencji w Locarno, doszło do polepszenia stosunków polsko-czechosłowackich, co znalazło wyraźne odzwierciedlenie w tonie informacji i komentarzy prasy czeskiej. Przez kilka kolejnych lat relacje bilateralne układały się poprawnie, po czym znowu nastąpiło powolne ich pogarszanie. Po podpisaniu zaś przez Polskę i Niemcy deklaracji o niestosowaniu przemocy z 1934 roku doszło, zdaniem autorki, do „załamania stosunków dyplomatycznych polsko-czechosłowackich" (s. 24).

Grażyna Pańko sygnalizuje również inne kwestie (moim zdaniem być może nawet ważniejsze), które rzutowały na (czytaj: utrudniały) relacje bilateralne polsko-czechosłowackie. Do nich należy m.in. odmienny stosunek tych krajów do Rosji, a także różnice charakteru i psychiki obu narodów (s. 21-23). Trudno nie zauważyć, że odmienne nastawienie obu krajów do Rosji w różnych okresach poważnie rzutowało na kontakty pomiędzy Pragą a Warszawą, bynajmniej ich nie ułatwiając. Panslawizm, z którym Czesi wiązali spore nadzieje pod koniec XIX i na początku XX wieku, nigdy nie zyskał równie dużych sympatii wśród Polaków. Czesi czuli się nieraz dotknięci zarzutami o ich nader przy jazny stosunek do Rosji i wręcz rusofilstwo, a sami z kolei krytykowali Polaków za ich ostentacyjną antyrosyjskość. 
Podpisanie w 1935 roku radziecko-czechosłowackiego traktatu Warszawa odebrała jako działanie antypolskie, co dodatkowo pogorszyło stosunki polsko-czechosłowackie w kolejnych latach.

Poważnym utrudnieniem w stosunkach czechosłowacko-polskich (zresztą niedocenianym przez wielu badaczy) była rywalizacja obu państw o ich miejsce i rolę w polityce środkowoeuropejskiej. Po rozpadzie Austro-Węgier Czechosłowacja pretendowała do wypełnienia próżni politycznej w Europie Środkowej, z Pragą, która miała przejąć przedwojenną rolę Wiednia i stać się centrum informacyjnym o Europie Środkowej. Czechosłowacja też, jak zapewniali jej przywódcy, miała służyć jako pomost pomiędzy Wschodem a Zachodem, Słowiańszczyzną a światem zachodnim. Politycy polscy swemu krajowi wyznaczali podobną rolę. Po I wojnie światowej zarówno Czechosłowacja, jak i Polska aspirowały do odegrania na tym polu decydującej roli, co stało się widoczne już w czasie obrad konferencji paryskiej, a potem także w kolejnych latach w całym okresie międzywojennym. Oba państwa rywalizowały również ze sobą o rolę najważniejszego sojusznika Francji w regionie. Nie tylko politycy polscy starali się wykorzystać położenie kraju, przedstawiając Polskę jako barierę antykomunistyczną i łącznik Zachodu ze Wschodem. Także Czesi aspirowali do podobnej roli, akcentując przy tym, że Czechosłowacja, jako inicjator i twórca Małej Ententy, była również ważnym czynnikiem stabilizującym w Europie Środkowej. Rywalizacja pomiędzy Polską a Czechosłowacja o przywództwo w Europie Środkowej znalazła także odbicie w ich stosunkach ze Stanami Zjednoczonymi. Politycy i dyplomaci obu państw prześcigali się w jak najkorzystniejszej prezentacji własnych krajów i ich roli w Europie Środkowej, próbując w ten sposób pozyskać poparcie USA w ważnych dla nich kwestiach.

Dobre stosunki Polski z Węgrami, a także popieranie przez niektóre ugrupowania polskie autonomistów słowackich utrudniało również bilateralne relacje pomiędzy Pragą a Warszawą. Od początku swego istnienia Czechosłowacja obawiała się przede wszystkim rewizjonizmu węgierskiego, starając się na różne sposoby przed nim zabezpieczyć. Temu też służyło powołanie przez Beneša Małej Ententy.

Sporo uwagi poświęca autorka opisowi różnych form kontaktów polsko-czechosłowackich (s. 50-71), poczynając od wizyt parlamentarzystów, senatorów i polityków. Ważną rolę we wzajemnym lepszym poznawaniu się odegrały wizyty intelektualistów i wymiana doświadczeń zawodowych w różnych dziedzinach. Dochodziło nieraz do współpracy dziennikarzy z obu krajów. To właśnie prasa, zwłaszcza codzienna, miała duże możliwości kształtowania opinii publicznej i oddziaływania na nią.

Jak pisze autorka: „Zdecydowanie najwięcej dla wzajemnego poznania się obu nacji i tym samym budowania przyjaznych stosunków mogły uczynić szeroko pojęte kontakty kulturalne" (s. 55). Rozwijano wymianę naukową polsko-czechosłowacka, a od 1922 roku rozpoczęto gościnne wykłady profesorów wyższych uczelni. Kontakty naukowe objęły także młodzież akademicką, której organizowano studyjne wyjazdy i fundowano stypendia. Współpraca w dziedzinie teatru, muzyki, litera- 
tury, rozmaite wykłady i spotkania oraz wieczorki i wycieczki z udziałem gości z obu krajów, a także okolicznościowe akademie i uroczystości rocznicowe zapoznawały $\mathrm{z}$ osiągnięciami kulturalnymi Polaków (i vice versa). Dzięki tego rodzaju kontaktom poszerzano stopniowo zakres wiedzy o sąsiedzkim kraju, choć trudno stwierdzić, czy było to wykorzystane dla celów politycznych. Jeśli tak, to raczej jedynie doraźnie i w niewielkim stopniu.

Rozdział II prezentuje opinie Czechów o Polakach w okresie międzywojennym. Jak pisze autorka ( s. 72 ): „Obraz Polaka i narodu polskiego w opinii czeskiej zawiera zdecydowanie więcej negatywów niż pozytywów". Wśród pozytywów często padały określenia „słowiański naród”, „patrioci”, „szlachetni i bohaterscy”, „dobrzy Słowianie”, „wojownicy”, „gościnni”. Najcieplej wyrażali się Czesi o Poznaniakach („pracowici, oszczędni, zdyscyplinowani, z charakterem”), dość przychylnie oceniali Polaków z Kongresówki, a najkrytyczniej mówili o Polakach z Galicji.

W lutym 1921 roku „České slovo” pisało: „Politycy warszawscy, posłowie i inna inteligencja diametralnie różni się w poglądach na konieczność porozumienia się z Czechami od tradycyjnych podżegaczy i nienawidzących Czechów - galicyjskich Polaków. Warszawscy działacze rządowi i publiczni nie lekceważą znaczenia przyjaznego współżycia z naszym narodem, jak to czynią działacze krakowscy i lwowscy, którzy w ślepej namiętności dla swej nietolerancyjnej mentalności nie patrzą w przyszłość" (s. 86). Tego rodzaju opinie nie były bynajmniej rzadkością, gdyż w podobnej tonacji wypowiadano się nieraz na łamach prasy i potem.

Czesi często wytykali Polakom „skłonność do bójek, działanie pod wpływem emocji”, „awanturniczość”, „drażliwość”, „grubiaństwo”, „zaborczość”, „chciwość i pazerność" (dotyczyło to włączanych przez Polskę terytoriów), „szowinizm”, „ekspansywność” etc. Nierzadko Polaka pokazywano jako „zdrajcę”, „Kaina”, „Judasza”, „tyrana”, „kłamcę”, „bez honoru”, „niegodziwego”. W kalejdoskopie tych surowych i nader krytycznych ocen i obelg nie zabrakło wielu innych, równie kategorycznych i ostrych. To wyraźnie negatywne nastawienie Czechów do Polaków nasiliło się po 1934 roku, co należy wiązać z sytuacją polityczną obu krajów i stanem stosunków pomiędzy nimi.

Podobnie zdecydowanie negatywne były opinie Czechów o Polsce i, jak pisze autorka, „można sądzić, że istniał związek między stanem stosunków polsko-czechosłowackich a nimi" (s. 136). Wśród niewielu cech pozytywnych wskazywano, że Polska pełniła rolę zapory przed bolszewizmem, była sojusznikiem Francji i należało się jej znaczące miejsce w Europie. Z uznaniem wyrażano się o kulturze polskiej („cytadela kultury zachodniej”), zwłaszcza literaturze i muzyce. Doceniano też konsolidację państwa polskiego i ogromną pracę wykonaną przez naród w odbudowie powojennej („entuzjazm twórczy”). Pozytywne opinie o Polsce nasiliły się z okazji obchodów 10-lecia jej niepodległości oraz Powszechnej Wystawy Krajowej, która miała miejsce w Poznaniu w 1929 roku. Pisano o sukcesach i odbudowie gospodarczej kraju, który w trudnych dla niego powojennych warunkach umacniał własną niepodległość. Budowę portu w Gdyni nazywano „iście amerykańskim 
przedsięwzięciem". Życzliwie komentowano także rozwój polskiej radiofonii i floty handlowej.

Ale, jak już wspomniano, wśród opinii Czechów o Polsce przeważały jednak głosy negatywne. Na początku lat dwudziestych często pisano o braku stabilizacji, niestałości granic Polski i potencjalnym zagrożeniu dla niej ze strony nieprzyjaciół. Samą Polskę tė̇ określano jako niebezpiecznego sąsiada i zagrożenie, także dla Pragi. W karykaturach nierzadko przedstawiano ja jako „państwo szlacheckie” (a więc złe), „klerykalne”, „niedemokratyczne”, „uciskające obywateli i mniejszości narodowe”, a ponadto „megalomańskie i aspirujące do mocarstwowej roli”. W podobnej tonacji wypowiadali się nieraz politycy, m.in. Edvard Beneš, także František Peroutka, Ivan Dérer, którzy krytycznie oceniali polską politykę zagraniczną ( „romantyczna i nierealistyczna”, hołdująca zasadzie „nie honorowo, ale zdrowo”). W drugiej połowie lat trzydziestych ton wielu wypowiedzi, zwłaszcza prasowych, zaostrzył się i nieraz określano Polskę jako „sekundanta Niemiec”, „dziecko niebezpiecznie grające z ogniem”, „marnotrawnego syna”. W prasie czeskiej często wytykano Polsce „nacjonalizm”, „imperializm”, „rewizjonizm”, „militaryzm”, „germanofilstwo”, a jej system polityczny nierzadko określano jako „dyktaturę” lub „faszyzm”.

„Obraz Polski i Polaka - jạk pisze autorka, s. 191-192 - zmieniał się w zależności od stanu stosunków polsko-czechosłowackich. Zdecydowanie negatywny był w latach napięć, a pozytywne akcenty widać wyraźnie w II połowie lat dwudziestych. Najbardziej pozytywnie widzieli nas ludzie, którzy byli w naszym kraju i znali Polaków dłużej. Zdecydowanie negatywnie wypowiadali się na nasz temat komuniści, ale pejoratywny ton widać i w opiniach przedstawicieli innych kierunków politycznych. Może najbardziej przyjaźnie nastawieni byli katolicy, pozostajacy jednak w mniejszości".

W tekście znalazło się trochę błędów literowych, które w przypadku nazwisk przestają być li tylko literówkami. Chodzi m.in. o czeskiego dyplomatę Ferdinanda Veverkę (a nie Vyverkę, s. 27-28), także o amerykańskiego senatora Williama. Boraha (a nie Boraka, s. 170). Ponadto Vacláv Girsa był posłem Czechosłowacji w Polsce (a nie konsulem, s. 191). I drobna sprawa redakcyjna. Nie bardzo wiadomo dlaczego niektóre pakty pisze się dużą literą (np. Pakt Czterech), a inne małą (pakt wschodni, s. 22, 171).

Lektura niniejszej książki uzmysławia jak niewiele wiedziano w międzywojennej Czechosłowacji o Polsce i jej sprawach. Skłania też do wielu gorzkich refleksji. Mimo bliskości - nie tylko geograficznej - obu krajów były one, jak się okazuje; dosyć odległe od siebie. Tym łatwiej można było, wykorzystując niewiedzę i emocje, kreować wizerunek Polski i Polaków.

\section{Halina Parafianowicz}

